\title{
Precision poultry farming: mapping attributes that influence laying birds in Nova Andradina/MS
}

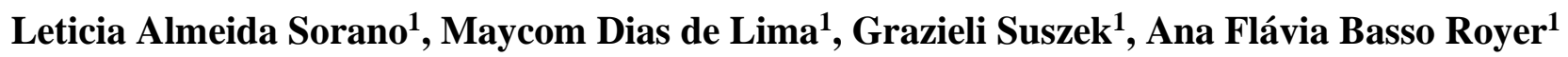 \\ ${ }^{1}$ Instituto Federal de Educação, Ciência e Tecnologia de Mato Grosso do Sul, Campus Nova Andradina, Nova Andradina, Mato \\ Grosso do Sul, Brasil. E-mail: leticia.sorano@gmail.com, maycomdyas@gmail.com,grazieli.suszek@ifms.edu.br, \\ ana.royer@ifms.edu.br
}

Received: 01/05/2020; Accepted: 05/08/2020.

\begin{abstract}
Precision poultry farming is related to effective monitoring of production stages and product quality. This work evaluated the influence of temperature, air humidity, and luminosity variables on chicken egg production and quality (internal and external), under uncontrolled environment and natural lighting, using precision poultry techniques. One hundred and sixty birds of Embrapa 51 line, reared in cages, were assessed with 24, 30, 50, and 70 weeks of life. Values of temperature, relative humidity, luminosity, and the samples for productivity and egg quality determination were collected in predefined locations in a poultry house belonging to IFMS, Nova Andradina/MS Campus. Spatial maps were generated using the inverse distance weighted interpolation (IDW). Environmental variables show significant correlations with production and internal/external quality parameters of chicken egg raised in uncontrolled environments. The use of spatial maps for environmental characteristics of the poultry house, production, and internal/external chicken egg quality provides better visualization of the variations and correlations among the investigated variables, assisting the process of decision-making related to appropriate management and optimization of the poultry house.
\end{abstract}

Keywords: precision poultry farming, egg quality, productivity.

\section{Avicultura de precisão: mapeamento de atributos que influenciam aves de postura em Nova Andradina/MS}

\section{RESUMO}

A avicultura de precisão está ligada ao monitoramento efetivo das etapas de produção e qualidade do produto. O trabalho avaliou a influência das variáveis temperatura, umidade do ar e luminosidade na produção e qualidade de ovos (interna e externa) de galinhas, sob ambiente não controlado e iluminação natural, utilizando técnicas de avicultura de precisão. 160 aves da linhagem Embrapa 51, criadas em gaiola, foram avaliadas com 24, 30, 50 e 70 semanas de vida; os atributos temperatura, umidade relativa, luminosidade e as amostras para determinação da produtividade e qualidade dos ovos foram coletados em pontos pré-definidos dentro do galpão avícola pertencente ao IFMS, Campus Nova Andradina/MS; os mapas espaciais foram gerados com uso do interpolador inverso do quadrado da distância (IQD). As variáveis ambientais apresentam correlação significativa com a produção e qualidade externa e interna de ovos de galinhas criadas em ambientes não controlados. $\mathrm{O}$ uso dos mapas espaciais para os atributos ambientais do galpão, produção e qualidade externa e interna de ovos de galinhas proporcionam uma melhor visualização das variações e correlações entre os atributos, auxiliando na tomada de decisão quanto ao manejo adequado e otimização do galpão.

Palavras-chave: avicultura de precisão, qualidade de ovos, produtividade. 


\section{Introduction}

Chicken egg production in the second trimester of 2019 (930.93 million of dozens) represented an increment of $5.8 \%$ concerning the same period of 2018 (857.60 million of dozens) and a $2 \%$ increase comparing the production of the first trimester of 2019 (IBGE, 2019). Due to the current demands, the search for knowledge and techniques that aim to optimize animal productivity at a lower cost has grown over the last few years (Ponciano et al., 2011).

Egg-laying poultry farming constitutes an increasing stimulus to agribusiness, excelling as an activity that sets Brazil in the path of development, standing it out at a global level. Being a grain producer country attributes positive values to the national trade balance, even considering aspects associated with population distribution, making Brazilian agricultural production reach positive rates. These previous conditions make precision poultry farming favorable (Albino et al., 2014).

The objective of using precision poultry is to improve microclimate inside the poultry house. It is possible to provide comfort to layers throughout the precise management of environmental variables (temperature, relative humidity) because climate conditions interfere with the egg production quality. The decision-making process becomes more effective through the analysis of the set of data obtained in the poultry house, as it is possible to optimize production time and identify internal and external factors that affect the productive results, deriving in economic gains (Revista Rural, 2019).

As previously reported for Allahverdi et al. (2013), birds exposed to high temperatures had decreased weight gain, reduction in feed consumption, reduced production, egg weight, and shell thickness. To design and adapt poultry facilities capable of maintaining temperature and relative humidity within limits that provide an ideal thermal environment inside the housing, adequate to birds' needs, without affecting production costs has become a challenge in poultry farming (Biaggioni et al., 2008).

In that context, studies that can correlate production and quality data related to the microclimate of the poultry house are sought, taking into account the production and animal welfare criteria, ensuring an increase in productivity using technical management that can favor the performance of laying birds.

This work evaluated the influence of temperature, air humidity, and luminosity variables on production and chicken egg quality (internal and external), under uncontrolled environment and natural lighting, using precision poultry techniques.

\section{Material and Methods}

The experiment was conducted in the poultry house for egg-laying birds belonging to the Federal Institute of Education, Science, and Technology of Mato Grosso do Sul, placed at Nova Andradina/MS, Fazenda Santa Bárbara, located at latitude $22^{\circ} 04^{\prime} 47^{\prime \prime} \mathrm{S}$ and longitude $53^{\circ} 27^{\prime} 19^{\prime \prime} \mathrm{W}$.

The climate of the region is classified, according to Köppen and Geiger (1928), as the tropical Aw megathermal climate, with little or no defined winter season, rain concentration in the summer months, and drought in winter, with an average of altitude of $380 \mathrm{~m}$. Climatological data for the analyzed dates are presented in Figure 1.

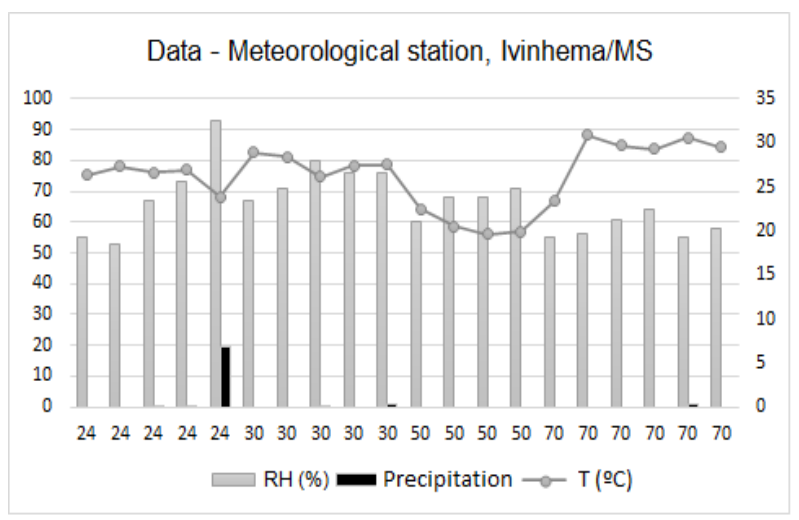

Figure 1 - Climatological data (Relative Humidity (RH), Precipitation, and Temperature (T)) for the weeks referring to the study, Ivinhema meteorological station. Source: Embrapa Western Agriculture (2020).

The egg-layers poultry house of the IFMS is a conventional type with positive ventilation, is $8.29 \mathrm{x}$ $62.56 \mathrm{~m}$ in size, with $3.5 \mathrm{~m}$ of ceiling height, ceramic tile coverage, concrete floor, and side curtains. The employed cages are also of the conventional type for egglaying (flat wire), having trough feeders, and nipple drinking troughs.

One hundred and sixty hens of the Embrapa 51 lineage were used, distributed in cages of $1 \mathrm{~m}$ long, 0.45 $\mathrm{m}$ wide, and $0.60 \mathrm{high}$, with the capacity to support up to 10 birds, placing five birds in each cage (Figure 2).

First, the poultry house was georeferenced, where a grid of sampling points was built covering its entire useful area (Figure 3). The surveys were carried out with birds of 24, 30, 50, and 70 weeks of age. Thus, the variables corresponding to the internal microclimate of the poultry house like temperature and relative humidity obeyed the predefined collecting points, enabling the creation of spatial maps of these parameters. 


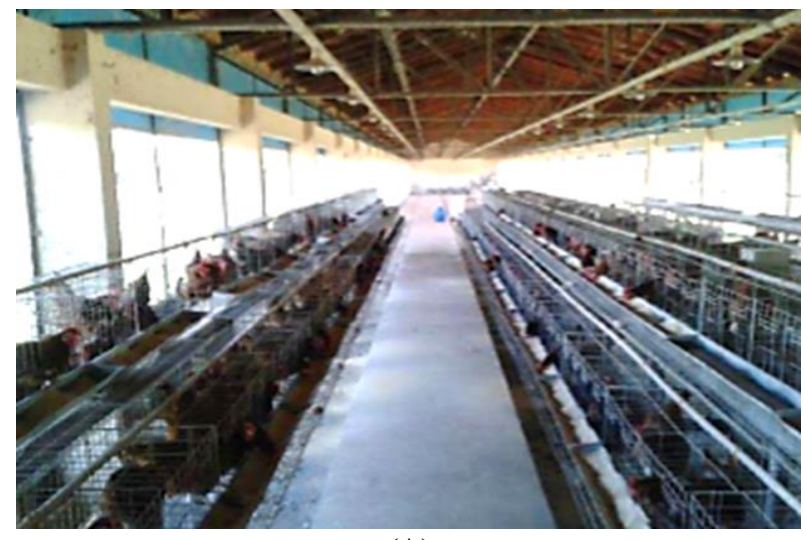

(A)

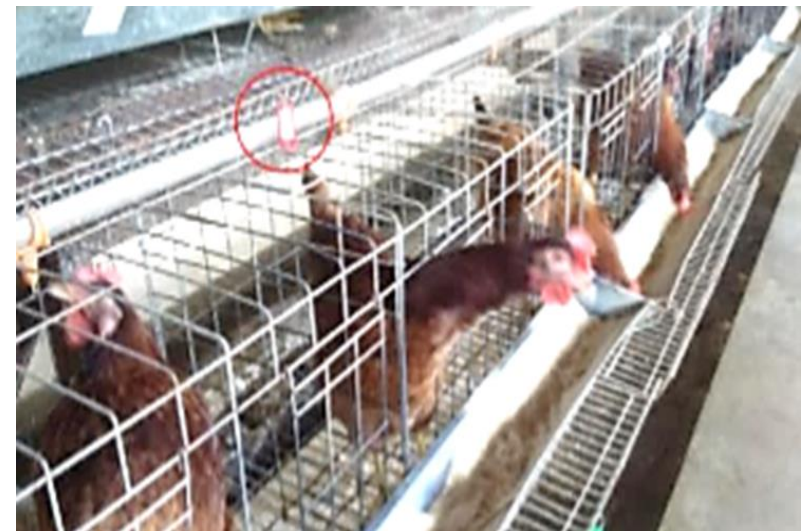

(B)

Figure 2- (A) Egg-laying aviary belonging to IFMS/NA and (B) cages with laying birds and identification plate of the sampling site.

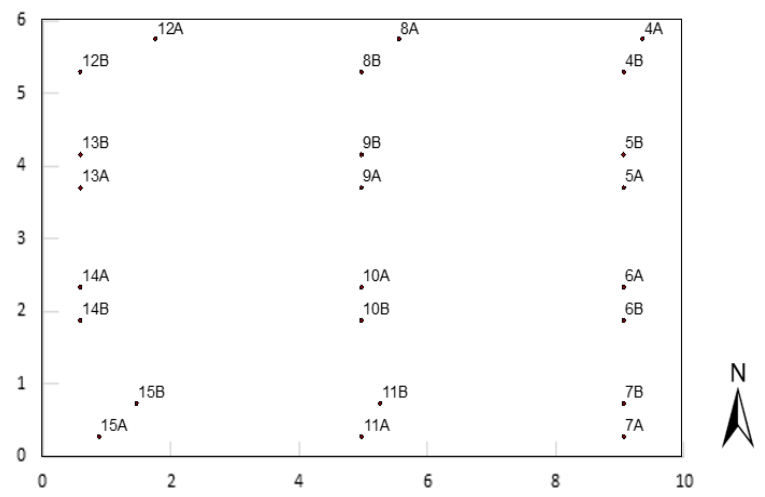

Figure 3 - Localization of sampling points in the egg-laying poultry house belonging to IFMS/ Nova Andradina Campus.

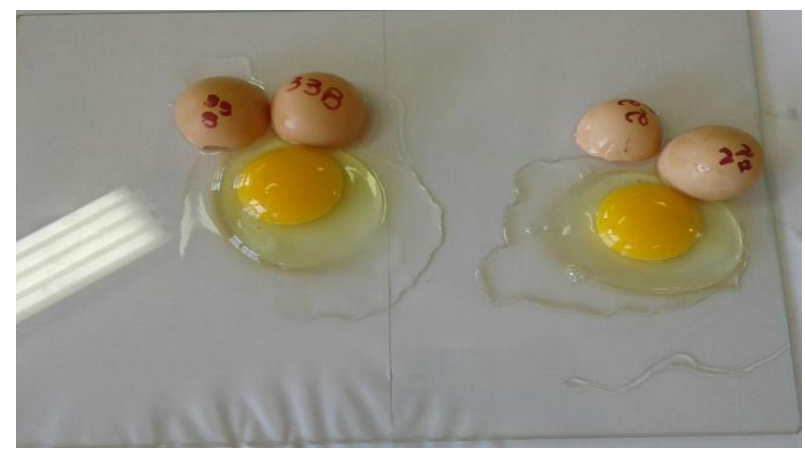

Figure 4 - Plane surface to evaluate the egg measurements.
The surveys of the egg quality (Haugh Units, yolk percentage, albumen percentage, and shell thickness) were carried out between August of 2018 and July of 2019 at predetermined periods, these being 24, 30, 50, and 70 weeks of age of the birds. The data collecting process of the internal microclimate of the poultry house was also performed in these predetermined periods, and its conditions (temperature, relative humidity, and natural luminosity) were evaluated three times a day: $07 \mathrm{~h}, 12 \mathrm{~h}$, and $17 \mathrm{~h}$.

Measurements of environmental variables were made using a digital Instrutherm Thermo-hygro-anemometerlux meter, with a precision of two decimal cases. All the investigated variables were assessed under natural conditions considering that the poultry house does not have any type of automated system. To determine Haugh Unit, the eggs were broken on a flat surface to obtain the albumen height (Figure 4), using a multi-Gauge height meter.

Shells resulting from the break were washed and dried at room temperature and then weighted to calculate the percentage of the eggshell (Figure 5).

The data were submitted to descriptive statistical analysis, using the Minitab $18^{\circledR}$ software to obtain the measures (mean and median), and dispersion measure (standard deviation), measures of the distribution shape (variation coefficient), Pearson correlation analysis, and Anderson Darling normality test.

Inverse distance weighting (IDW) was chosen as an interpolator, and the spatial maps were made using Surfer ${ }^{\circledR} 15$ software. The IDW is a univariate deterministic interpolator of weighted averages, that is, the more distant an observed point is from the estimated, the less its influence on the inference value. This method is considered accurate enough when compared to Kriging, and, in some cases, shows similar results (Souza et al., 2010).

Data obtained were analyzed using Pearson's linear correlation to verify the relationship between the investigated parameters and the construction of thematic maps for spatial analysis and their layout on the inside of the poultry house.

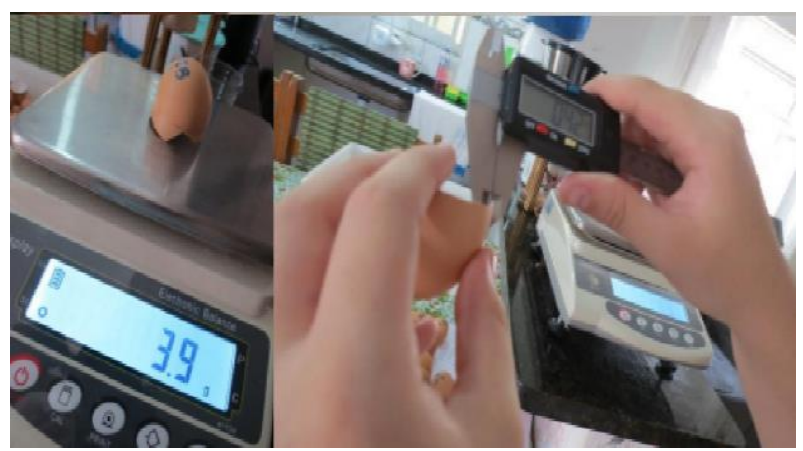

Figure 5 - Dried eggshell analysis. 


\section{Results and Discussion}

Thermal factors such as temperature, humidity, thermal radiation, and air movement are fundamental for the vital function of birds, directly affecting egg production and sometimes may be considered even more important than homeothermy itself. In that regard, those factors were analyzed (Table 1). It was possible to observe higher values for relative humidity (RH) and internal temperature $\left(\mathrm{T}^{\circ}\right)$ of the poultry house in the birds' 30th and 70th weeks of age, showing values of $69.09 \%$ and $64.01 \%$ for $\mathrm{RH}$ and $31.44^{\circ} \mathrm{C}$ and $32.61{ }^{\circ} \mathrm{C}$ for $\mathrm{T}^{\mathrm{o}}$, respectively. On the other hand, luminosity (Lux) reached higher values in the 50th and 70th weeks, probably influencing an increased production in the 70th week when compared to the $30^{\text {th }}$, which also presented unsatisfactory thermal conditions in the observed period.

According to Avila et al. (2017), for Embrapa 51 lineage, usually, the production peak occurs in the 30th week contrasting the information obtained in this study where the birds reached only $45.9 \%$ of their productive potential in this period. There was a strong drought in the region at the time, with high temperatures (Figure 1); however, high levels of RH (65.42 to $69.09 \%)$ were observed inside the poultry house (Table 1 ).

Table 1 - Descriptive statistical analysis of the productivity and environmental variables data.

\begin{tabular}{|c|c|c|c|c|c|c|c|c|c|}
\hline & Weeks & Average & Median & $\begin{array}{l}\text { Standard } \\
\text { deviation }\end{array}$ & Kurtosis & Asymmetry & Minimum & Maximum & CV \\
\hline \multirow{4}{*}{$\begin{array}{c}\text { Production } \\
(\%)\end{array}$} & 24 & 92.7 & 94.95 & 0.90 & 1.44 & -0.98 & 55.05 & 97.00 & 14.57 \\
\hline & 30 & 45.9 & 45 & 0.85 & -0.28 & 0.16 & 19.95 & 70.05 & 27.80 \\
\hline & 50 & 84.15 & 79.95 & 1.06 & 1.61 & 1.43 & 64.95 & 98.00 & 18.92 \\
\hline & 70 & 75 & 75 & 1.22 & -0.70 & -0.32 & 45 & 89.00 & 24.32 \\
\hline \multirow{4}{*}{ Egg weight (g) } & 24 & 50.77 & 50.68 & 1.63 & 0.34 & 0.29 & 47.98 & 54.82 & 3.20 \\
\hline & 30 & 50.02 & 50.85 & 4.12 & 12.45 & -3.11 & 33.19 & 54.06 & 8.24 \\
\hline & 50 & 60.23 & 60.20 & 2.33 & -0.53 & -0.51 & 55.09 & 63.49 & 3.87 \\
\hline & 70 & 60.30 & 60.43 & 2.17 & -0.87 & -0.02 & 56.46 & 64.20 & 3.59 \\
\hline \multirow{4}{*}{$\begin{array}{l}\text { Diameter } \\
(\mathbf{m m})\end{array}$} & 24 & 47.17 & 47.16 & 0.80 & 3.64 & -1.03 & 44.91 & 48.45 & 1.71 \\
\hline & 30 & 46.66 & 47.40 & 3.31 & 21.58 & -4.54 & 31.48 & 48.80 & 7.09 \\
\hline & 50 & 50.49 & 50.06 & 2.46 & 11.30 & 2.25 & 48.80 & 60.71 & 5.39 \\
\hline & 70 & 49.57 & 49.79 & 1.85 & 4.03 & -1.75 & 44.05 & 51.78 & 3.72 \\
\hline \multirow{4}{*}{$\%$ yolk } & 24 & 26.30 & 26.25 & 0.79 & 0.58 & 0.04 & 24.59 & 28.13 & 3.00 \\
\hline & 30 & 27.31 & 27.85 & 2.31 & 13.20 & -3.26 & 17.78 & 29.60 & 8.45 \\
\hline & 50 & 29.74 & 29.65 & 1.16 & -0.94 & 0.42 & 28.21 & 31.88 & 3.90 \\
\hline & 70 & 31.00 & 30.90 & 1.09 & 0.46 & -0.02 & 28.80 & 33.51 & 3.53 \\
\hline \multirow{4}{*}{$\%$ albumen } & 24 & 64.83 & 65.02 & 1.00 & 0.47 & -0.27 & 62.40 & 66.88 & 1.54 \\
\hline & 30 & 62.24 & 62.88 & 4.33 & 19.63 & -4.23 & 42.78 & 66.25 & 6.96 \\
\hline & 50 & 60.71 & 61.20 & 1.84 & 3.92 & -1.72 & 54.63 & 62.69 & 3.03 \\
\hline & 70 & 60.53 & 60.64 & 1.21 & 0.38 & 0.03 & 57.87 & 63.20 & 2.00 \\
\hline \multirow{4}{*}{$\%$ shell } & 24 & 8.87 & 8.76 & 0.40 & -0.57 & 0.53 & 8.22 & 9.69 & 4.50 \\
\hline & 30 & 9.07 & 9.14 & 0.84 & 9.31 & -0.94 & 6.11 & 11.48 & 9.23 \\
\hline & 50 & 9.55 & 9.12 & 1.32 & 7.50 & 2.85 & 8.62 & 13.79 & 3.80 \\
\hline & 70 & 8.47 & 8.46 & 0.34 & 0.90 & -0.56 & 7.58 & 9.07 & 3.96 \\
\hline \multirow{4}{*}{$\begin{array}{c}\text { Haugh unit } \\
\text { (HU) }\end{array}$} & 24 & 78.11 & 78.47 & 3.89 & -0.77 & 0.06 & 70.66 & 84.99 & 4.98 \\
\hline & 30 & 71.98 & 72.77 & 5.14 & -0.28 & 0.07 & 62.37 & 82.78 & 7.14 \\
\hline & 50 & 78.22 & 78.22 & 2.72 & 4.12 & 1.42 & 74.70 & 87.24 & 3.48 \\
\hline & 70 & 61.00 & 60.32 & 5.20 & -0.36 & 0.01 & 49.46 & 69.51 & 8.52 \\
\hline \multirow{4}{*}{$\begin{array}{l}\text { Yolk Index } \\
\text { (YI) }\end{array}$} & 24 & 0.40 & 0.41 & 0.02 & -0.03 & -0.33 & 0.37 & 0.43 & 3.92 \\
\hline & 30 & 0.39 & 0.39 & 0.03 & 9.59 & -2.56 & 0.27 & 0.43 & 7.82 \\
\hline & 50 & 0.42 & 0.42 & 0.02 & 1.92 & -0.71 & 0.36 & 0.46 & 5.18 \\
\hline & 70 & 0.42 & 0.42 & 0.02 & 7.40 & 1.79 & 0.37 & 0.50 & 5.58 \\
\hline \multirow{4}{*}{$\begin{array}{c}\text { Temperature } \\
\left(\mathbf{T}^{\mathbf{o}}\right)\end{array}$} & 24 & 30.20 & 30.19 & 0.16 & -1.59 & 0.12 & 29.98 & 30.47 & 0.52 \\
\hline & 30 & 31.44 & 31.45 & 0.17 & 0.77 & -0.77 & 30.99 & 31.66 & 0.53 \\
\hline & 50 & 26.63 & 26.62 & 0.08 & -0.13 & 0.20 & 26.49 & 26.81 & 0.31 \\
\hline & 70 & 32.61 & 32.58 & 0.22 & -1.54 & 0.13 & 32.29 & 32.93 & 0.67 \\
\hline \multirow{4}{*}{$\begin{array}{c}\text { Relative } \\
\text { Humidity } \\
\text { (RH\%) }\end{array}$} & 24 & 60.23 & 60.59 & 1.87 & 4.24 & -1.75 & 54.70 & 63.31 & 3.11 \\
\hline & 30 & 67.58 & 67.81 & 0.84 & 1.19 & -0.84 & 65.42 & 69.09 & 1.25 \\
\hline & 50 & 53.87 & 53.88 & 0.72 & 0.20 & 0.13 & 52.37 & 55.54 & 1.33 \\
\hline & 70 & 62.69 & 62.86 & 1.15 & 1.90 & -1.33 & 59.39 & 64.01 & 1.84 \\
\hline \multirow{4}{*}{$\begin{array}{l}\text { Luminosity } \\
\text { (Lux) }\end{array}$} & 24 & 150.15 & 145.94 & 57.84 & -0.33 & 0.42 & 55.89 & 271.22 & 38.52 \\
\hline & 30 & 153.00 & 112.00 & 119.07 & 2.62 & 1.76 & 46.44 & 472.00 & 77.83 \\
\hline & 50 & 369.31 & 180.89 & 504.18 & 5.26 & 2.44 & 46.56 & 2023.44 & 136.52 \\
\hline & 70 & 180.42 & 152.00 & 76.85 & -0.54 & 0.88 & 94.78 & 323.00 & 42.60 \\
\hline
\end{tabular}


Albino et al. (2014) reported that this decreased egglaying of the birds might be due to the combination of high levels found for environmental variables such as temperature and relative humidity interfering in the birds' welfare and productivity. Baêta and Souza (2010) also explained that body heat dissipation by evaporative processes has a direct impact on egg productivity and quality.

Besides, the lowest values regarding egg weight $(50.02 \mathrm{~g})$, diameter $(46.66 \mathrm{~mm})$, and yolk index (0.39) were also observed for the 30th week. The second-worst value of the Haugh Unit was found for the same period, reinforcing the idea of the influence of environmental variables since the worst conditions of the whole evaluated period (24th to 70th bird weeks of life ) were registered in that week. Consequently, egg production and quality also showed inferior results.

Best results can be seen in the 50th week when production capacity was $84.15 \%$, egg weight was $60 \mathrm{~g}$, Haugh Unit was 78.22 (good quality standard for this parameter is above $72 \mathrm{HU}$ ) (USDA Egg - Grading Manual, 2000), yolk index of 0.42 (average values in newly laid eggs are between 0.40 and 0.42 ), and an average diameter of $50.49 \mathrm{~mm}$. When these parameters are related to internal climatic factors, it can be noticed that the lowest average temperatures $\left(26.63{ }^{\circ} \mathrm{C}\right)$ and $\mathrm{RH}$ (53.87\%), and the highest incidence of light (369.31 Lux) derived in increased egg production with better quality as well. Better indoor conditions favor poultry farming as reported for Santana et al. (2018), the ideal temperature range for layers is between 18 and $28^{\circ} \mathrm{C}$.

Percentages of yolk, albumen, and shell found appear to be in the expected patterns. According to Ordóñez et al. (2005), eggs should present an average weight of $58 \mathrm{~g}$, consisting of 8 to $11 \%$ of the shell, around 56 to $61 \%$ of albumen, and 27 to $32 \%$ of yolk, with a gradual increase in yolk percentage and a gradual reduction in albumen percentage with the birds aging.
Concerning the variation coefficient of the analyzed attributes, only production and luminosity presented great variations. Luminosity presented heterogeneous data (> $30 \%$ ), which can be an interesting factor for analyses of spatial variability in the interior of the poultry house.

For better data analysis, a linear correlation was performed between all factors evaluated for the period of 24 to 70 weeks of the birds' life. The results presented in Table 2 show that there is a negative influence of temperature on the Haugh Unit (-0.25) and on shell percentages, that is, temperature raisings tend to reduce these attributes. Relative humidity can positively influence percentages of production (0.57) and albumen (0.23), meaning that ideal conditions of RH can improve egg production and albumen percentage and when occurs reduction of RH, shell (-0.30) and yolk index (-0.31) can increase for they are negatively correlated factors.

Although high variations of luminosity (>30\%) (Table 1), direct correlations with the shell percentage were observed. Higher light rates can increase the percentage of the shell. However, lower rates can reduce weight $(-0.23)$, diameter $(-0.40)$, percentage of yolk ($0.57)$, and percentages of albumen (-0.58) as well as yolk index, meaning that direct incidence of light can reduce egg quality, but proper handling of the curtains in the poultry house may positively impact quality.

To understand the attributes variation within the poultry house, spatial maps were created with general means, shown in Figures 6 and 7. From the production map, it is possible to verify that the production and the Haugh Unit (UH) presented higher values in the central area of the poultry house. Also, analyzing environmental conditions maps at the same location, it was found that temperature, humidity, and luminosity values are within the medium range. Regions where there are better thermal comfort present higher production and increased egg quality.

Table 2 - Correlation analysis of investigated attributes.

\begin{tabular}{|c|c|c|c|c|c|c|c|c|c|c|c|c|}
\hline & $\% W$ & Weight & Diam & $T^{o}$ & $U R$ & $L U X$ & $H U$ & $\% y$ & $\% a$ & $\% s$ & Shell & $Y I$ \\
\hline & 1.00 & & & & & & & & & & & \\
\hline Weight & 0.16 & 1.00 & & & & & & & & & & \\
\hline Diam & 0.06 & 0.67 & 1.00 & & & & & & & & & \\
\hline$T^{o}$ & 0.00 & -0.17 & -0.02 & 1.00 & & & & & & & & \\
\hline$R H$ & 0.57 & 0.05 & 0.01 & 0.37 & 1.00 & & & & & & & \\
\hline$L U X$ & $\overline{-0.12}$ & -0.23 & $\underline{-0.40}$ & $-\overline{-0.42}$ & -0.12 & 1.00 & & & & & & \\
\hline$H U$ & 0.16 & 0.03 & -0.05 & -0.25 & -0.11 & -0.12 & 1.00 & & & & & \\
\hline$\% y$ & 0.11 & 0.03 & $\underline{0.42}$ & 0.10 & -0.21 & -0.57 & 0.24 & 1.00 & & & & \\
\hline$\% a$ & 0.09 & 0.68 & $\overline{0.73}$ & 0.17 & 0.23 & $\underline{-0.58}$ & 0.15 & 0.27 & 1.00 & & & \\
\hline$\% s$ & 0.01 & -0.02 & -0.05 & -0.29 & -0.30 & $\underline{0.40}$ & -0.12 & -0.07 & $\underline{-0.39}$ & 1.00 & & \\
\hline Shell & 0.32 & 0.16 & $\underline{0.37}$ & -0.01 & $\overline{0.15}$ & -0.08 & 0.14 & 0.33 & $\overline{0.11}$ & -0.21 & 1.00 & \\
\hline$Y I$ & -0.27 & 0.09 & $\overline{0.18}$ & 0.03 & -0.31 & -0.47 & 0.26 & $\underline{0.45}$ & 0.29 & 0.17 & -0.30 & 1.00 \\
\hline
\end{tabular}



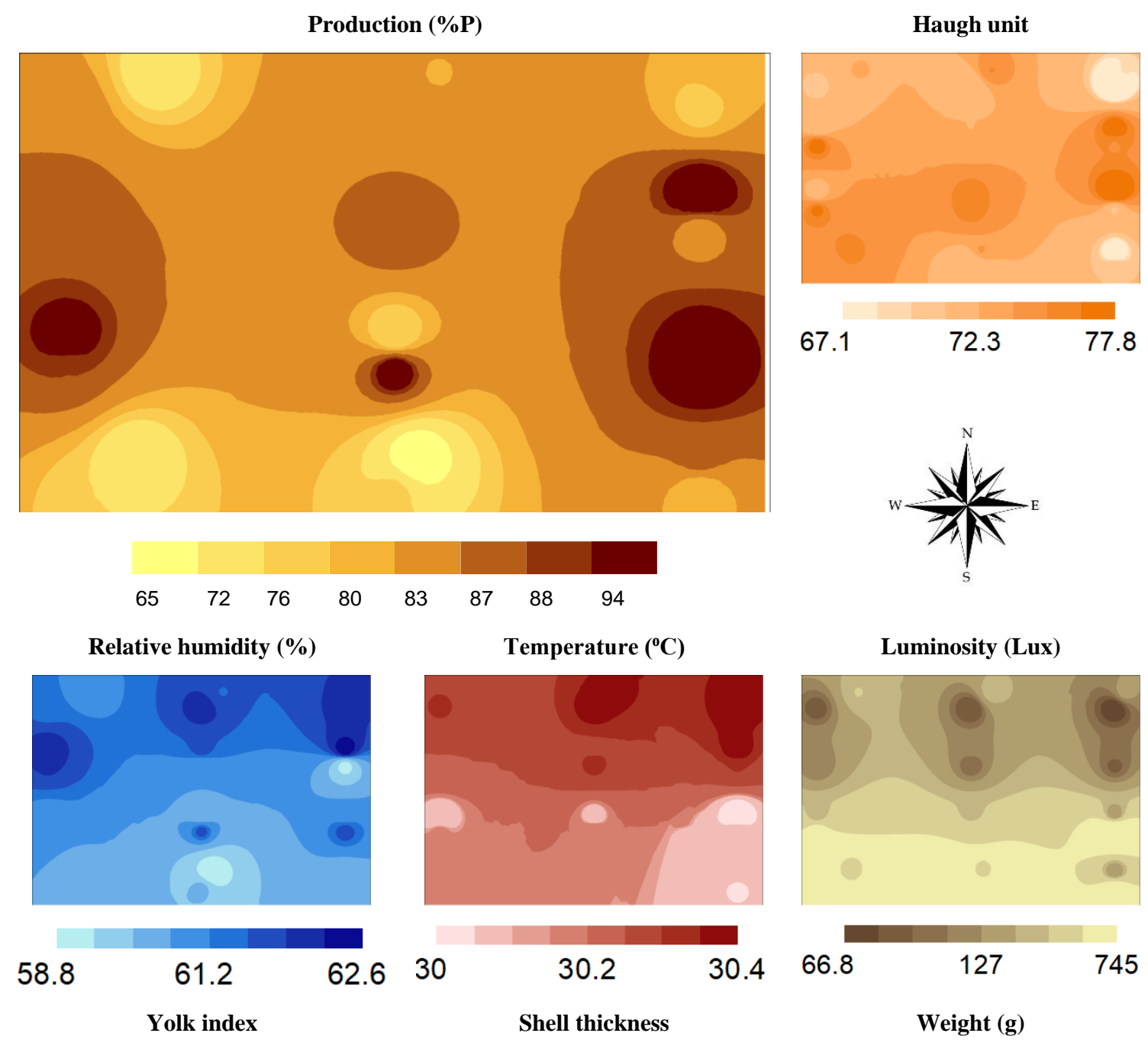

\section{8

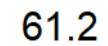

62.630

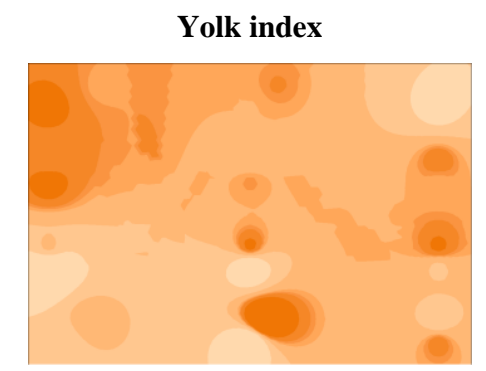

\subsection{7}

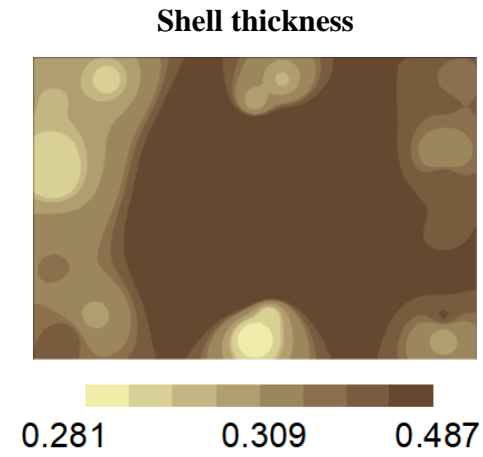

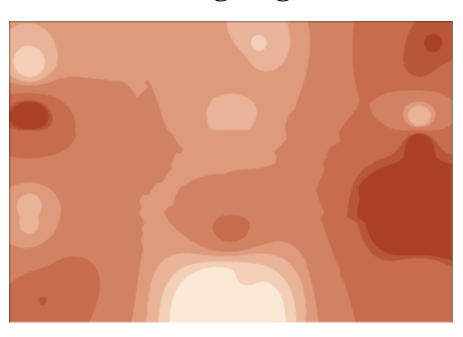

50.6

56.2

58

Figure 6 - Thematic maps of the birds laying weeks for the environmental variables temperature, relative humidity, and luminosity of the poultry house belonging to IFMS, Nova Andradina Campus.

\%Yolk

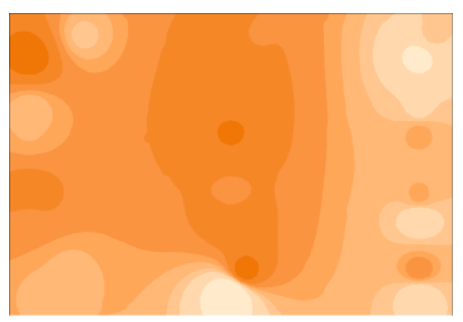

26.8

28.6

29.6
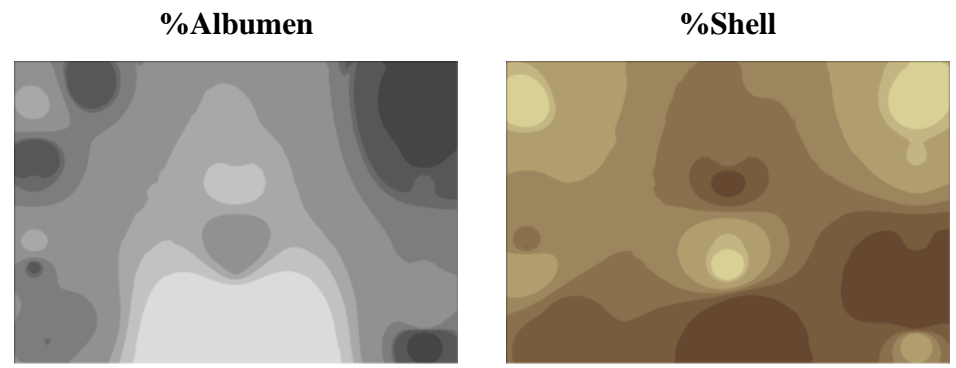

55.6

62.3

$63.6 \quad 8.67$

8.98

9.75 
Relative humidity (\%)

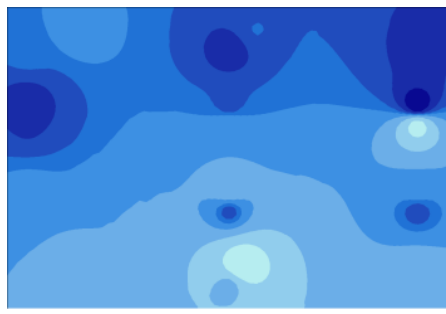

58.8 61.2 62.630

Temperature $\left({ }^{\circ} \mathrm{C}\right)$

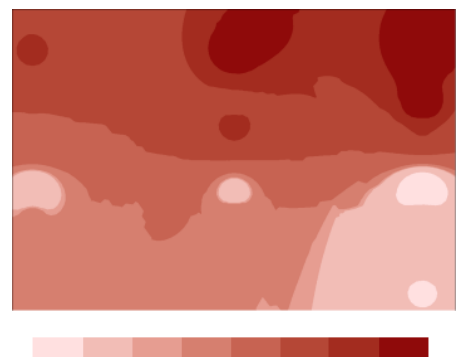

30.2

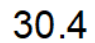

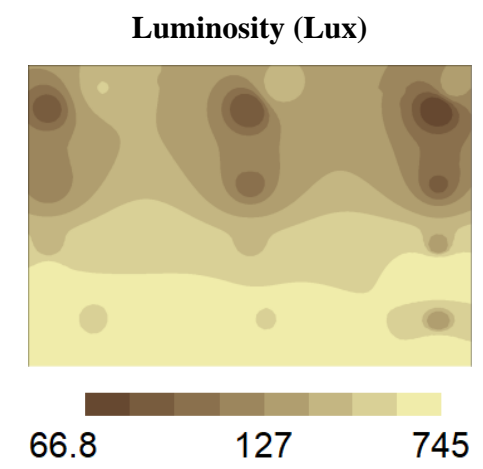

Figure 7 - Thematic maps of the laying weeks of the birds for the environmental variables temperature, relative humidity, and luminosity of the poultry house compared to the interferences of yolk, albumen, and shell percentages.

In the east and west regions, higher production percentages, egg weight, and UH are observed. These two regions have the lowest temperatures, relative humidity, and average luminosity, as well as the smallest shell thickness.

Environmental temperatures above the thermal comfort zone affect the bird, causing it to reduce feeding, and consequently decreases the size of the egg. The performance of birds is affected by temperature showing reduced food consumption and energy deviation in an attempt to maintain their body temperature (Jácome et al., 2007; Tinôco, 2001)

It was also noticed that the southern region of the poultry house had lower temperatures $(\mathrm{T})$, relative humidity (RH) and luminosity (Lux), visually showing the influence on yolk, albumen, and shell percentages (Figure 7). It is possible to visually verify that the South region presented lower albumen and yolk percentages but also higher shell percentages.

Table 2 shows significant negative correlations between luminosity and the percentages of albumen ($0.58)$ and yolk $(-0.57)$ but also positive correlations with the shell percentage $(0.40)$. These trends can be appreciated in the maps in Figure 7, in which regions with the highest luminosity have the lowest yolks and albumen percentages and the highest shell percentages.

\section{Conclusions}

The use of spatial maps for the environmental factors of the poultry house, production, and external and internal quality of chicken eggs provide better visualization of the variations and correlations between the different parameters, helping in the decision-making process regarding the proper management and optimization of the poultry house.

The environmental variables (temperature, relative humidity, and luminosity) have a significant correlation with the production and external and internal quality of chicken eggs reared in uncontrolled environments. The luminosity of the poultry house showed a significant influence on yolk, albumen, and eggshells percentages coming from chicken raised in uncontrolled environments. The temperature of the shed showed a negative correlation with the Haugh Unit and the shell percentage. In contrast, for relative humidity, the correlation was positive with production and albumen percentages and negative with shell percentage and yolk index.

\section{Bibliographic References}

Albino, L.F.T., Carvalho, B.R., Maia, R.C., Barros, V.R.S.M., 2014. Galinhas poedeiras: criação e alimentação, primeira ed. Aprenda Fácil, Viçosa.

Allahverdi, A., Feizi. A., Takhtfooladi, H.A., Nikpiran, H., 2013. Effects of heat stress on acid-base imbalance, plasma calcium concentration, egg production and egg quality in commercial layers. Global Veterinária, 10(2), 203-207. DOI: 10.5829/idosi.gv.2013.10.2.7286.

Avila, V.S., Figueiredo, E.A.P., Krabbe, E.L., Duarte, S.C., Saatkamp, M.G., 2017. Poedeira Embrapa 051 - guia de manejo das poedeiras coloniais de ovos castanhos, primeira ed. Embrapa Suínos e Aves, Concórdia.

Baêta, F.C., Souza, C.F., 2010. Ambiência em edificações rurais: conforto animal, segunda ed. Editora UFV, Viçosa.

Biaggioni, M.A.M., Mattos, S.P.J., Targa, L.A., 2008. Desempenho térmico de aviário de postura acondicionado naturalmente. Semina: Ciências Agrárias, 29(4), 961-972. DOI: $10.5433 / 1679-0359$.

EMBRAPA. Embrapa Agropecuária Oeste, 2020. Ministério da Agricultura, Pecuária e Abastecimento. Guia Clima, Dourados.

IBGE. Instituto Brasileiro de Geografia e Estatística, 2019. Ministério da Economia. Estatística da Produção Pecuária, abr.jun. 2019. Brasília, Ministério da Economia, 9 p.

Jácome, I.M.T.D., Furtado, D.A., Leal, A.F., Silva, J.H.V., Moura, J.F.P., 2007. Avaliação de índices de conforto térmico de instalações para poedeiras no nordeste do Brasil. Revista Brasileira de Engenharia Agrícola e Ambiental, 11(5), 527-531. DOI: $10.1590 / \mathrm{S} 1415-43662007000500013$ 
Köppen, W., Geiger, R., 1928. Klimate der Erde. Gotha, Verlag Justus Perthes.

Ordóñez, J.A., 2005. Tecnologia de Alimentos: alimentos de origem animal - vol. 2, primeira ed. Porto Alegre, Artmed.

Ponciano, P.F., Lopes, M.A., Yanagi Junior, T., Ferraz, G.A.S., 2011. Análise do ambiente para frangos por meio da lógica Fuzzy: uma revisão. Archivos Zootecnia, 60(R), 1-13. DOI: 10.21071/az.v60i232.4913.

Revista Rural, 2019. Avicultura de Precisão. https://www.revistarural.com.br/2019/04/01/avicultura-deprecisao/ (acessado 18 de abril de 2020).

Santana, M.H.M., Saraiva, E.P., Costa, F.G.P., Figueiredo Junior, J.P., Santana, A.M.M.A., Alves, A.R., 2018. Ajuste dos níveis de energia e proteína e suas relações para galinhas poedeiras em diferentes condições térmicas. Pubvet, 12(1), 112. DOI: 10.22256/pubvet.v12n1a20.1-12.

Souza, G.S., Lima, J.S.S., Xavier, A.C., Rocha, W.S.D., 2010. Krigagem ordinária e inverso do quadrado da distância aplicados na espacialização de atributos químicos de um argissolo. Scientia Agraria, 11(1), 73-81. DOI: 10.5380/rsa.v11i1.15939.

Tinôco, I.F.F., 2001. Avicultura industrial: novos conceitos de materiais, concepções e técnicas construtivas disponíveis para galpões avícolas brasileiros. Revista Brasileira de Ciência Avícola, 3(1), 1-25. DOI: 10.1590/S1516635X2001000100001.

USDA. United States Department of Agriculture, 2000. Egg grading manual. Washington, 56 p. (Agricultural Handbook, 75). 